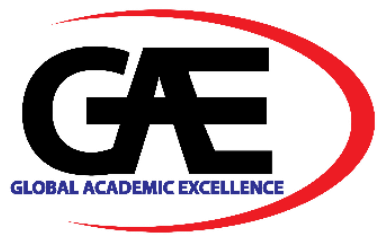

\title{
THE PROCESS APPROACH TO THE TEACHING OF WRITING: FOCUS ON PROCESS RATHER THAN PRODUCT
}

\author{
Wardatul Akmam Din ${ }^{1}$, Suyansah Swanto ${ }^{2 *}$, Nur Anneliza Abd Latip ${ }^{3}$, Iziana Hani Ismail ${ }^{4}$ \\ $1 \quad$ Faculty of Psychology and Education, Universiti Malaysia Sabah, Malaysia \\ Email: wardadin@ums.edu.my \\ 2 Faculty of Psychology and Education, Universiti Malaysia Sabah, Malaysia \\ Email: suyansah@ums.edu.my \\ 3 Preparatory Centre for Science \& Technology, Universiti Malaysia Sabah, Malaysia \\ Email: nuranne@ums.edu.my \\ 4 Preparatory Centre for Science \& Technology, Universiti Malaysia Sabah, Malaysia \\ Email: iziana.hani@ums.edu.my \\ * Corresponding Author
}

\section{Article Info:}

\section{Article history:}

Received date: 11.09 .2021

Revised date: 10.10 .2021

Accepted date: 15.11 .2021

Published date: 30.11 .2021

\section{To cite this document:}

Din, W. A., Swanto, S., Abd Latip, N. A. \& Ismail, I. Z. (2021). The Process Approach To The Teaching Of Writing: Focus On Process Rather Than Product. Journal of Information System and Technology Management, 6 (23), 63-71.

DOI: $10.35631 /$ JISTM.623005

This work is licensed under $\underline{\mathrm{CC} B Y} 4.0$

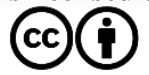

\section{Abstract:}

Composition writing has always been an integral part of the English Language curriculum in primary, secondary and tertiary education in Malaysia, yet being the most difficult of the four skills in English as a Second Language; the teaching of writing has often been neglected. Process writing, as distinguished from 'Product Writing', is playing a large role in ESL classes. Writing is seen as a communicative act with an intended purpose and audience. The teacher and other learners help the writer find a topic and revise drafts of a written piece until it conveys the intended meaning. While working to make their meanings clear, learners are assumed to acquire competence using the style, syntax, grammar and surface features of the language. During the writing process, students engage in pre-writing, planning, drafting and post-writing activities. However, learners do not necessarily engage in these activities in that order because the writing process is recursive in nature. Language rules are taught in teacher-led- mini-lessons but always in the context of expressing the learners' own ideas. This paper reports on a study that explores how a process-oriented approach to writing influences a group of university ESL students.

Keywords:

Process Approach, Product Approach, English Writing Skill 


\section{Introduction}

Writing is a complex skill, and concerns about how to teach this skill are not new. In general, Malaysian students perform unsatisfactorily in English language examination, especially in the writing section (Razali,2013; Azman, 2016; Din, W, 2013; Nursazwani et al., 2018; Din et al., 2020; Kee \& Razali, 2019). In composition, educators have been moving towards an emphasis on process, rather than product, and in consequence, there are a variety of available sources providing research findings on how students learn to write, suggesting new teaching strategies, and arguing for curricular changes.

Much discussion (Kee \& Razali, 2019; Martinez-Calderon, et al., 2020) has centred on the process-centred theory of writing, but many participants do not fully understand what constitutes process writing, or on what the process paradigm is based. The Literacy Dictionary (Harris \& Hodges, 1995:195) defines process writing as "a writing instruction model that views writing as an ongoing process ... in which students follow a given set of procedures for planning, drafting, revising, editing, ... and publishing ... their writing”.

It was not until the early 1970s that proper consideration was given by teachers and educators as to why some writers were good and others were not. This signalled the emergence of the process approach, with its emphasis on writing as a process rather than on product. By moving away from the strictly controlled classroom environment created by the product approach, the process approach concentrates on the classroom as a writing workshop. Here, students work collaboratively in small groups and are encouraged to master a range of behaviours associated with effective composition. When ideally applied, the process approach emphasizes group activities geared towards the students' compositions evolving through many stages: discovering things to say about a topic, drafting, pausing, sharing work in progress, revising, and editing. The teacher's role becomes that of facilitator, moving between the groups of students, offering advice and suggestions rather than dictating the outcome. The aim of the process approach is to concentrate on the stages of the work, not on the result.

\section{Literature Review}

Several different research relating to the process approach have been undertaken. Perl (1978, 1979), Sommers (1978) and Pianko, (1979) undertook research into the problems faced by basic writers when starting the process of composition were carried out in the late 1970s. A further significant research was carried out by Flower and Hayes (1981) into the composing process. In 1983, Graves carried out a longitudinal study marking the importance of teachers' perceptions of the writing needs of students in the development of students. In the same year, Calkins conducted a case study in an elementary school that provided insights into how children learn to write as well as the impact that teaching practices have on children's development as writers. Berkenkotter, in 1991, attempted to reconcile cognitivist and social epistemic rhetoric. In 1996, Hayes provided useful framework that expanded on his 1980 model. In 1998, Westervelt investigated the impact of the process approach on middle school students.

The above research into L1 writing allow some general observations to be made. From being perceived as a purely mechanical activity, whereby writing was simply the recording of ideas on paper and students produced predetermined products, the perceptions have altered so that writing was viewed as being creative process which involved the discovery of meaning. This change of perception brought with it a new attention to the students. 
These research were translated into instructional guidelines for five stages of the writing process (Graham and Sandmel, 2011):

(1) engaging in prewriting tasks,

(2) creating an initial draft,

(3) revising the text,

(4) editing for conventions; and

(5) publishing or presenting a polished final draft.

In Malaysia, teachers started to implement instruction in these stages in the 1980s through such practices as conducting writers' workshops, having students complete multiple drafts of their papers, holding frequent individual and small-group conferences with students, and encouraging peer review of written products. Process Writing is one of the methodologies that are explicitly indicated in the national Malaysian curriculum and syllabi, as well as in the Malaysia Education Blueprint (2013-2025) (ELSQC, MOE,2015).

The emphasis within the process approach is on assisting students through the various stages of composing. It does not simply look at the result of the writing process. Students collaborate in small groups, usually containing five members, each working with the aim of supporting the others. A central feature of the process approach is the notion of the classrooms as a writing workshop, in which students share their work. Teachers act as coaches or facilitators, providing constant support to students as they create several drafts in the development of their compositions.

White and Arntd (1991) say that focusing on language errors 'improves neither grammatical accuracy nor writing fluency' and they suggest instead that paying attention to what the students say will show an improvement in writing.

Research (Maarof et al., 2011; Yunus, Nordin, Salehi, Redzuan, \& Embi, 2013) also shows that feedback is more useful between drafts, not when it is done at the end of the task after the students' hand in their composition to be marked. Corrections written on compositions returned to the student after the process has finished seeming to do little to improve student writing.

The emphasis in a process-oriented classroom is on process rather than on product (Palpanadan et al., 2015; Annamalai, 2016). Students attempt to master the behaviours that characterise good writers, with the teacher offering advice and suggestions. Activities focus on writing, discussing drafts, and rewriting. Consequently, an important difference between the productand the process-oriented classroom is that in the latter students do much more writing.

Mukundan (2011) also stated that the transition to a process-based approach in Malaysian classrooms in the early 1980s was dramatic, with many obstacles such as a lack of resources for teaching writing through process, huge class sizes, and overly reliant students. Instead of benefiting from the learner-driven flexibility and writing, students acquired challenges, frustrations, and fear as they tried to write draughts and peer evaluations, and teacher help via conferences was hardly available (Mukundan, 2011). 
Special Issue: Foundation Program Education Post-Covid-19: Issues and Opportunities As with most other complex skills, people through education bring bad habits or poorly learned techniques to the writing process. Weak writers, for example, tend to assume that the only reader of their essays will be the teacher, who already knows what the topic is, so they fail to identify the topic explicitly in their text.

In most cases, students adopt more effective writing behaviours when they are encouraged on the spot. Advocates of the process model therefore propose that effective teachers think of themselves as coaches in a workshop environment. So, they interfere regularly in the learning process, immediately correcting those things students do wrong and praising those things they do right, giving reinforcement when it is most useful and most beneficial. Such intervention requires that teachers ask students to produce multiple drafts of an assignment. Class time is devoted to revising drafts on the basis of feedback that the teachers, as well as fellow students, provide.

Whilst not all writing goes through the all the stages that the process approach contends form the complex interaction of activities that lead to a finished paper, perhaps because there is insufficient time in the writing process, or the student is not presented with the opportunity, the stages are generally accepted as reflecting the development of successful writing. These stages are prewriting, drafting, pausing, reading, revising, editing, and publishing.

\section{Methodology}

This study is a case study based of one class that was taught by the writer over a period of 14 weeks. This study focuses on a group of thirty undergraduates' reaction to a series of writing classes offered by the writer who uses a process-oriented approach to writing in English as a second language. As such, its purpose is to enhance understanding (both the researcher's and that of other interested parties) of the complex process of teaching ESL writing.

The research method adopted for this paper was quantitative, where data on a group of Malaysian undergraduates taught using the process writing approach were collected and analysed. The analysis looked for improvement if any between the essays produced during the 14 weeks of intervention. They were marks of Pre-, Post- and Delayed Post Intervention Essays.

\section{Findings}

The literature shows that little is known or has been published about English writing ability and the achievement of Malaysian undergraduates. This research is like a new small piece of a jigsaw puzzle in the wide field of ESL writing.

The process writing approach to teaching writing is an idea that first emerged three decades ago. It has been used in many classrooms in many countries with different types of learners, implemented by different types of interpretations and teaching styles (Reyes, 1991; Unger and Fleischman, 2004). This approach teaches the students to make use of writing strategies to help them with their writing. For example, students are taught to take a wider view of the revising process than to simply make changes in mechanics and form: instead, they are taught to revise for changes in discourse and voice. This approach aims to turn students into active writers and encourages them to be brave in their approach. Their development extends beyond the learning of basic writing skills. It is a familiar concept, especially to the western world. However, 
Volume 6 Issue 23 (November 2021) PP. 63-71 DOI: 10.35631/JISTM.623005

Special Issue: Foundation Program Education Post-Covid-19: Issues and Opportunities despite all of this, it is still not given proper emphasis in the Malaysian English language curriculum.

Therefore, research in this area may contribute not only to a better understanding of the nature of the process writing approach but may also help to identify the Malaysian students' strengths and weaknesses in the construct. This information will be very useful for curriculum development and improving their performance.

This set of data is comprised of pre-, post- and delayed post-intervention essay marks of the experimental group as presented in the table 1 below:

\begin{tabular}{|c|c|c|c|}
\hline Student ID & $\begin{array}{c}\text { Pre- } \\
\text { interventio } \\
\text { n Essays }\end{array}$ & $\begin{array}{c}\text { Post- } \\
\text { interventio } \\
\text { n Essays }\end{array}$ & $\begin{array}{c}\text { Delayed } \\
\text { Post- } \\
\text { interventio } \\
\text { n Essays }\end{array}$ \\
\hline 1 & 61 & 73 & 71 \\
\hline 2 & 46 & 53 & 53 \\
\hline 3 & 46 & 49 & 48 \\
\hline 4 & 63 & 77 & 75 \\
\hline 5 & 63 & 78 & 74 \\
\hline 6 & 65 & 77 & 75 \\
\hline 7 & 62 & 80 & 77 \\
\hline 8 & 47 & 58 & 57 \\
\hline 9 & 62 & 77 & 75 \\
\hline 10 & 70 & 78 & 75 \\
\hline 11 & 47 & 54 & 51 \\
\hline 12 & 51 & 58 & 57 \\
\hline 13 & 75 & 80 & 80 \\
\hline 14 & 53 & 68 & 65 \\
\hline 15 & 75 & 80 & 80 \\
\hline
\end{tabular}

\begin{tabular}{|c|c|c|c|}
\hline Student ID & $\begin{array}{c}\text { Pre- } \\
\text { interventio } \\
\text { n Essays }\end{array}$ & $\begin{array}{c}\text { Post- } \\
\text { interventio } \\
\text { n Essays }\end{array}$ & $\begin{array}{c}\text { Delayed } \\
\text { Post- } \\
\text { interventio } \\
\text { n Essays }\end{array}$ \\
\hline 16 & 47 & 59 & 57 \\
\hline 17 & 67 & 78 & 78 \\
\hline 18 & 53 & 58 & 58 \\
\hline 19 & 57 & 69 & 67 \\
\hline 20 & 71 & 78 & 75 \\
\hline 21 & 42 & 47 & 44 \\
\hline 22 & 47 & 47 & 47 \\
\hline 23 & 61 & 69 & 67 \\
\hline 24 & 63 & 77 & 75 \\
\hline 25 & 57 & 74 & 75 \\
\hline 26 & 73 & 78 & 76 \\
\hline 27 & 66 & 74 & 75 \\
\hline 28 & 67 & 78 & 76 \\
\hline 29 & 71 & 77 & 75 \\
\hline 30 & 63 & 64 & 63 \\
\hline
\end{tabular}

Table 1: Pre-, Post-, Delayed Post-intervention Essays Results

In this analysis, the paired-samples t-test is used for the matched group i.e. pre- intervention essays results and post-intervention essays results of essay writing in which pairs of subjects that are matched on one characteristic (e.g., essay writing results) served in this case three conditions, i.e. before the experimental group was exposed to the intervention, after 14 weeks of exposure to the intervention and finally after a gap of one month upon completing the 14 weeks intervention.

Three sets of pairs were investigated: pair 1 (Pre-Intervention Essay Results - Post Intervention Essay Results), pair 2 (Pre-Intervention Essay Results - Delayed Post), and pair 3 (PostIntervention Essay Results - Delayed Post). Table 4.28 indicates that there is a significant difference in the results of essay writing between Pre-Intervention Essay Results and PostIntervention Essay results, $\mathrm{t}(\mathrm{df}=29)=-8.833, \mathrm{p}<0.01$ for pair 1 . Likewise, similar results appear for pair 2 between Pre-Intervention Essay Results and Delayed Post, $\mathrm{t}(\mathrm{df}=29)=-8.630$, $\mathrm{p}<0.01$. However, there is insignificant difference in the results of essay writing between PostIntervention Essay results and Delayed Post Results, $\mathrm{t}(\mathrm{df}=29)=0.0333, \mathrm{p}=0.662$ for pair 3 . 
Volume 6 Issue 23 (November 2021) PP. 63-71 DOI: 10.35631/JISTM.623005

Special Issue: Foundation Program Education Post-Covid-19: Issues and Opportunities

\begin{tabular}{|c|c|c|c|c|c|c|c|}
\hline & & Mean & $\begin{array}{l}\text { Std. } \\
\text { Deviation }\end{array}$ & $\begin{array}{l}\text { Std. } \\
\text { Error } \\
\text { Mean }\end{array}$ & $t$ & $\mathrm{df}$ & $\begin{array}{l}\text { Sig. (2- } \\
\text { tailed) }\end{array}$ \\
\hline Pair 1 & $\begin{array}{l}\text { Pre Int Results - } \\
\text { Post Int Results }\end{array}$ & -1.5667 & .9714 & .1774 & -8.833 & 29 & .000 \\
\hline Pair 2 & $\begin{array}{l}\text { Pre Int Results - } \\
\text { Delayed Post }\end{array}$ & -1.5333 & .9732 & .1777 & -8.630 & 29 & .000 \\
\hline Pair 3 & $\begin{array}{l}\text { Post Int Results - } \\
\text { Delayed Post }\end{array}$ & .0333 & .4138 & .0756 & .441 & 29 & .662 \\
\hline
\end{tabular}

Table 2: Paired Differences of Pre-, Post- and Delayed Post Intervention Essay Results

The mean values as presented in Table 2 shows that significantly better exam results were obtained for the Post Intervention Essay Results $(\mathrm{M}=7.233)$ than the Pre-Intervention Essay Results $(M=5.667)$ for pair 1 , and the Delayed Post Results $(M=7.200)$ than the Pre-Test Results $(M=5.667)$ for pair 2. However, pair 3 has different results of which the Post Intervention Essay Results ( $M=7.233)$ received better examination results than the Delayed Post Results $(M=7.200)$. In other words, the students' performance after the one-month lapse did not show any deterioration or any further improvement. Hence, it would appear that not only was the intervention possible to improve students' writing performance, but such improvement persisted and was a predictor of academic success in essay writing.

\begin{tabular}{|ll|l|l|}
\hline & & Mean & Std. Deviation \\
\hline Pair 1 & Pre Test Results & 5.667 & 2.0057 \\
\cline { 2 - 4 } & Post Test Results & 7.233 & 2.3146 \\
\hline \multirow{2}{*}{ Pair 2 } & Pre Test Results & 5.667 & 2.0057 \\
\cline { 2 - 5 } Pair 3 & Delayed Post & 7.200 & 2.3693 \\
\hline & Post Test Results & 7.233 & 2.3146 \\
\hline
\end{tabular}

\section{Table 3: Paired Samples Statistics of Pre-, Post- and Delayed Post Tests Results}

From the analysis above, it is safe to conclude that there is evidence of improvement in the students' writing performance after 14 weeks of exposure to the intervention as compared to their results before the intervention. The delayed post-intervention essay results could indicate retention among the experimental students.

This analysis demonstrates evidence of improvement in the students' writing performance after 14 weeks of exposure to the intervention as compared to their results before the intervention. The delayed post-intervention essay results could indicate retention among the experimental students. 
In terms of language structure, the good students seemed to have improved from good to better, and the weaker groups managed to write a more coherent and cohesive essays. All these resulted in the increase of their post and delayed post-intervention essay marks.

As for result from the students' essays, it could be observed that when all three groups were compared, the medium group improved the most while the good group improved the least. The medium group students seemed to have predominantly benefited from the intervention as they showed improvements in terms of essay quality when compared from pre-intervention essays to the delayed-intervention essays.

The problems and difficulties that all three groups faced were nearly similar, which were difficulties in writing the thesis statement, hook, bridge, topic sentences and also the paragraph conclusion. However, we can safely conclude that after 14 weeks of exposing them to the intervention, the students appeared to have improved their essays based on the observable reduction in the number of errors in the essays produced.

However, one of the fundamental assumptions in the process-oriented approach to writing, i.e. 'discovery of meaning' which is a trend in studies by researchers of first and second language writing (e.g.Raimes, 1985; Zamel, 1982,1983) did not seem to be suitable for this group of students.

Some of the students lack experience in the language being used for the writing work and have limited competency in that language (Chan et. al., 2003). Some of the students lacked commitment. It is found that for these less advanced and/or less motivated second language learners this assumption of the process approach to writing may not be applicable. From this research, the students were heavily reliant on their instructor's guidance, which indicates that unskilled ESL learners need a lot of help from their instructor.

Group discussions and the peer review process were also inhibited by the students' weakness in English. The finding in this study illustrates that whilst working with peers who were at a higher level appeared to stimulate the learning of those at a lower skill level, those higher-level students did not feel that they had benefited from contributions made by their less-skilled peers. However, it is worth noting that in helping their less-able classmates, the more skilful students did, in fact, derive benefits because by providing support in this way they were able to consolidate their own understanding. However, students need a lot of time and training to become accustomed to, and proficient in, this activity.

\section{Conclusion}

This study shows that the process-oriented approach to writing aids the development of undergraduate ESL writers' writing skills. It has proven that the approach serves the different needs of students from differing backgrounds. However, care needs to be exercised to ensure that a flexible approach is taken. Instructors need to remember that students do not all have the same level of proficiency or ability. It is crucial that modifications are made so that the methods of instruction are suitably tailored for individual students. Instructors need to be aware of the different ways that individual students learn most effectively, including the ways in which ESL learners acquire literacy. Armed with this knowledge, instructors should be able 


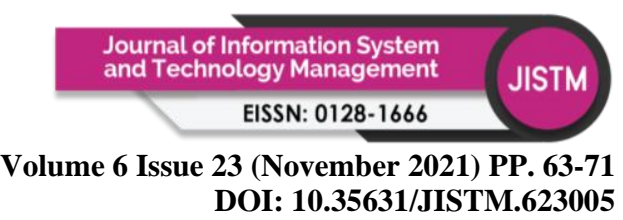

Special Issue: Foundation Program Education Post-Covid-19: Issues and Opportunities to become not merely facilitators but also mediators, and thus create culturally and linguistically sensitive environments for all learners.

\section{References}

Ali, Z. and M. Md Yunus, (2004). An ESL Writing Course: Unravelling Students' Needs and Concerns. The English Teacher Vol XXXIII December 2004. Retrieved on 9.07.06 from: http://www.melta.org.my/modules/sections/index.php?op=viewarticle\&artid=35

Annamalai, N. (2016). Exploring the writing approaches in the Facebook environment. Teaching English with Technology, 16(1), 71-87.

Azman, H. (2016). Implementation and challenges of English language education reform in Malaysian primary schools. The Southeast Asian Journal of English Language Studies, 22(3), 65-78.

Berkenkotter, C. (1991). Paradigm debates, turf wars, and the conduct of sociocognitive inquiry in composition. College composition and Communication, 42: 151-169.

Calkins, L. (1983). Lessons from a child: On the teaching and learning of writing. ed. Heinemann., Portsmouth, New Hampshire.

Chan, S.H. Ain Nadzimah and Tan, H, (2003). Malaysian ESL Academic Writing Skills: Establishing knowledge bases, attitudes and processes. Studies in Foreign Language Education. 18: 143- 156.

Dana F. and J. S. Hedgcock, (2004). Teaching ESL Composition: Purpose, Process, and Practice. Mahwah, NJ: Lawrence Erlbaum.

Din, W. A. (2013). The effects of a process approach on the writing of tertiary level ESL students in Malaysia. Unpublished MPhil. Dissertation, University of Manchester, UK.

Din, W. A., Saikim, F. H., Swanto, S., Latip, N. A. A., Ismail, I. H., \& Rasit, M. R. A. (2020). Students' Perspectives on The Effectiveness of Problem-Based Learning with Inverted Classroom Assistance in Improving Understanding of Foundations Courses (Persepsi Pelajar Terhadap Keberkesanan Pembelajaran Berasaskan Pemasaalahan dengan Bantuan Inverted Classroom untuk Memperbaiki Pemahaman Pelajar dalam KursusKursus Asas). Akademika, 90(2).

Flower, L. and J. Hayes, (1981). A cognitive process theory of writing. College Composition and Communication, 32: 365-387.

Gomez, R., R. Parker, R. Lara-Alecio and L. Gomez, (1996). Process Versus Product Writing with Limited English Proficient Students. The Bilingual Research Journal. Vol. 20(2): 209-233.

Graham, S., \& Sandmel, K. (2011) The Process writing approach: A Meta-analysis. The Journal of Educational Research, 104(6), 396-407.

Graves, D., 1983. Teachers and children at work., ed. Heinemann. London and Portsmouth, New Hampshire.

Harris, T. L., and R. E. Hodges, (1995). The literacy dictionary: The vocabulary of reading and writing. Newark, DE: International Reading Association.

Hayes, J. (1996). A new framework for understanding cognition and affect in writing, in The science of writing., C.M. Levy and S. Ransdell, Editors. Lawrence Erbaum Associates: Mahwah, NJ. p. 1-27.

Kee, L. L., Razali, A. B., Noordin, N., \& Samad, A. A. (2018). The role of digital technologies in facilitating the learning of ESL writing among TESL pre-service teachers in Malaysia: A review of the literature. The Journal of Asia TEFL, 15(4), 1139-1145. 
Volume 6 Issue 23 (November 2021) PP. 63-71 DOI: 10.35631/JISTM.623005

Special Issue: Foundation Program Education Post-Covid-19: Issues and Opportunities

Maarof, N., Yamat, H., \& Kee, L. L. (2011). Role of teacher, peer and teacher-peer feedback in enhancing ESL students' writing. World Applied Sciences Journal 15 (Innovation and Pedagogy for Lifelong Learning), 29-35.

Martinez-Calderon, Jesus \& Perez, Elica \& Lopez Diaz, Alexander. (2020). USING PROCESS WRITING IN THE TEACHING OF ENGLISH AS A FOREIGN LANGUAGE. Revista Caribeña de Investigación Educativa (RECIE). 4. 49-61. 10.32541/recie.2020.v4i1.pp49-61.

Mukundan, J., Mahvelati, E. H., Din, M. A., \& Nimechisalem, V. (2013). Malaysian secondary school students' ESL writing performance in an intensive English program. World Applied Sciences Journal, 22(12), 1677-1684.

Nursazwani, B. D., Dg, Din, W. A., \& AlSaqqaf, A. (2018). Exploring the vaw method of writing among Esl primary pupils: Conceptual paper. International Journal of Applied Linguistics and English Literature, 7(4), 248-252. Available at: https://doi.org/10.7575/aiac.ijalel.v.7n.4p.248.

Palpanadan, S. @ T., Ismail, F., \& Salam, A. R. (2015). Role of model essays in developing students writing skills in Malaysian schools: A review of literature. Mediterranean Journal of Social Sciences, 6(2), 56-61.

Perl, S. (1978).Five writers writing: Case studies of the composing processes of unskilled college writers. New York University.

Perl, S. (1979). The composing processes of unskilled college writers. Research in the Teaching of English, 13: 317-336.

Pianko, S. (1979). A description of the composing process of college freshman writers. Research in the Teaching of English, 13:5-22.

Raimes, A. (1985). What unskilled ESL Students do as they write: A classroom study of composing. TESOL Quarterly, 19:229-258.

Razali, A. B. (2013). Malaysian teachers ${ }^{\text {ee }}$ conceptions and uses of digital technology in English writing instruction: A multiple case study. (Doctoral dissertation). Retrieved from ProQuest Dissertations \& $\quad$ Theses Global. (https://search.proquest.com/docview/1426850

Sommers, N. (1978). Revision and the composing process: A case study of college freshman and experiences adult writers, Boston University.

Unger, J. and S. Fleischman. (2004). Is process writing the 'write stuff'? Educational Leadership, 62(2):90-91.

Westervelt, L. (1998). Teaching writing using the process-oriented approach., in Huntington Beach city school district (Eric Reproduction Service No. ED 420 864): Huntington Beach, California (Report research 143).

White, R. and V. Arndt. (1991). Process Writing. Longman.

Yunus, M. M., Nordin, N., Salehi, H., Redzuan, N. R., \& Embi, M. A. (2013). A review of advantages and disadvantages of using ICT tools in teaching ESL reading and writing. Australian Journal of Basic and Applied Sciences, 7(4).

Zamel, V. (1982). Writing: The process of discovering meaning. TESOL Quarterly., 16:159209.

Zamel, V. (1983). The composing processes of advanced ESL students: Six case studies. TESOL Quarterly, 17: 165-187. 